\title{
"NOT AS A STRANGER": NON-EMPLOYEE UNION ORGANIZERS SOLICITING ON COMPANY PROPERTY*
}

Section 7 of the National Labor Relations Act guarantees employees the right of self-organization. ${ }^{1}$ Employees may exercise this right by engaging in organizing activities on company property. ${ }^{2}$ However, the employer may restrict the exercise of this right in order to prevent interference with efficient plant production and discipline ${ }^{3}$ as long as no discrimination occurs. ${ }^{4}$ Thus, the employer may always prohibit union organizing by employees during working hours," but during nonworking hours employees may be barred from soliciting only where special circumstances indicate actual or potential interference with plant operation. ${ }^{6}$ Where the organizers seeking to solicit on company property are non-employees, the extent to which section 7 protects their

*NLRB v. Seamprufe, Inc., 222 F.2d 858 (10th Cir. 1955), denying enforcenent to 109 N.L.R.B. 24 (1954), cert. granted, 350 U.S. 818 (1955); NLRB v. Babcock and Wilcox Co., 222 F.2d 316 (5th Cir. 1955), denying enforcement to 109 N.L.R.B. 485 (1954), cert. granted, 350 U.S. S18 (1955) ; NLRB v. Monsanto Chemical Co., 225 F.2d 16 (9th Cir. 1955), denying enforcement to 108 N.L.R.B. 1110 (1954), petition for cert. filed, 24 U.S.L. WEEK 3123 (U.S. Nov. 1, 1955) (No. 492).

1. Section 7 provides that "employees shall have the right to self-organization, to form, join, or assist labor organizations, to bargain collectively through representatives of their own choosing. . ." 49 STAT. 452 (1935), as amended, 29 U.S.C. $\$ 157$ (1952). Under $\$ \$(1)$ it is an unfair labor practice for an employer to "interfere with, restrain, or coerce employees in the exercise of the rights guaranteed in section 7." 49 STAT. 452 (1935), as amended, 29 U.S.C. $\$ 158$ (a) (1) (1952). The Taft-Hartley amendments left the quoted portions of these sections unchanged. The purpose of the statute is to foster self-organization and collective bargaining as a solvent to industrial ills. 49 STAT. 449 (1935), as amended, 29 U.S.C. $\$ 151$ (1952) ; NLRB v. Cities Service Oil Co., 122 F.2d 149, 152 (2d Cir. 1941).

2. Republic Aviation Corp. v. NLRB, 324 U.S. 793 (1945). Prior to the enactment of the statute the employer had full authority to regulate conduct on his property by virtue of property and contract principles. See Daykin, Employees' Right to Organize on Company Tine and Company Property, 42 IrL. L. REv. 301 (1947).

3. Republic Aviation Corp. v. NLRB, supra note 2, at 797-98; Peyton Packing Co., 49 N.L.R.B. \$28, 843 (1943), enforcement granted, 142 F.2d 1009 (5th Cir. 1944), cert. denied, 323 U.S. 730 (1945). In general, an employer may enforce such rules as the proper conduct of his business requires. NLRB v. Mylan-Sparta Co., 166 F.2d 485 (6th Cir. 1948); NLRB v. Hudson MLotor Car Co., 128 F.2d 528 (6th Cir. 1942).

4. It is an unfair labor practice for the employer to prohibit union activities while allowing anti-union activities, NLRB v. Harbison-Walker Refractories Co., 135 F.2d 837 (8th Cir. 1943) ; NLRB v. William Davies Co., 135 F.2d 179, 181 (7th Cir. 1943), commercial solicitation, United Aircraft Corp., 67 N.L.R.B. 594 (1946), or even charitable solicitation, Standard-Coosa-Thatcher Co., 85 N.L.R.B. 1358, 1365 (1949).

5. E.g., NLRB v. Edinburg Citrus Ass'n, 147 F.2d 353 (5th Cir. 1945) ; accord, Peyton Packing Co., 49 N.L.R.B. 828, 843 (1943), enforcement granted, 142 F.2d 1009 (5th Cir. 1944), cert. denied, 323 U.S. 730 (1945).

6. E.g., NLRB v. La Salle Steel Co., 178 F.2d 829 (7th Cir. 1949), cert. denied, 339 U.S. 963 (1950). Paid lunch periods are considered employees' own time. Olin Industries v. NLRB, 191 F.2d 613 (5th Cir. 1951). Where union activity may interfere with customer 
activities is in doubt. In general, the employer's ability to exclude them has been held to depend not only on whether interference with plant operation will result, but also on whether the opportunity exists for solicitation off company premises. ${ }^{7}$ If no opportunity exists, because the nature of the employer's business requires employees to work and live in an isolated place like a lumber camp, non-employees may solicit on the premises. ${ }^{8}$ But absent such extreme circumstances, it is not clear what sort of opportunity for off-premises solicitation will justify the employer in prohibiting access to his property. ${ }^{9}$

In three cases recently decided by circuit courts of appeals, NLRB v. Seamprufe, Inc., ${ }^{10}$ NLRB v. Babcock and Wilcox Co., ${ }^{11}$ and NLRB v. Monsanto Chemical Co., ${ }^{12}$ non-employee organizers were denied access to company property under substantially identical circumstances. In each case the organizers had sought to distribute literature on company parking lots during nonworking hours. ${ }^{13}$ Traffic conditions made distribution at the plant entrance hazardous, ${ }^{14}$ and there was no opportunity for distribution at any point between the plant entrance and the nearby town in which most of the employees lived. ${ }^{15}$ Under these circumstances the NLRB had found that effective solicitation could not be

relations, as on the selling floors of department stores, solicitation may be prohibited at all times. NLRB v. May Dep't Stores Co., 154 F.2d 533 (8th Cir. 1946). See also note 41 infra.

7. E.g., Ranco, Inc., 109 N.L.R.B. 998, 1000 (1954), enforcement granted, 222 F.2d 543 (6th Cir.), cert. granted, 350 U.S. 894 (1955). The Supreme Court has rejected the argument that employees' ability to solicit on company property depends upon a showing of inadequate opportunity off the premises. Republic Aviation Corp. v. NLRB, 324 U.S. 793, 798 (1945). Some courts apparently regard the Republic "no-interference" test as applicable to both employees and non-employees. Bonwit Teller, Inc. v. NLRB, 197 F.2d 640, 645 (2d Cir. 1952) (dictum), cert. denied, 345 U.S. 905 (1953) ; Maryland Drydock Co. v. NLRB, 183 F.2d 538, 542 (4th Cir. 1950) (dictum).

8. E.g., NLRB v. Lake Superior Lumber Corp., 167 F.2d 147 (6th Cir. 1948) ; Weyerhauser Timber Co., 31 N.L.R.B. 258 (1941) ; W. T. Carter and Brother, 90 N.L.R.B. 2020 (1950) (company town) ; cf. NLRB v. Cities Service Oil Co., 122 F.2d 149 (2d Cir. 1941) (union representatives permitted aboard ship to investigate seamen's grievances).

9. Adequate opportunity for solicitation off company property has been found where organizers can effectively solicit at or near the plant entrances of company property. E.g., Associated Dry Goods Corp., 103 N.L.R.B. 271, 272 (1953) ; Mooresville Mills, 99 N.L.R.B. 572 (1952) ; Newport News Children's Dress Co., 91 N.L.R.B. 1521 (1950); see NLRB v. Carolina Mills, Inc., 190 F.2d 675 (4th Cir. 1951), enforcing 92 N.L.R.B. $1141,1142,1166$ (1951).

10. 222 F.2d 858 (10th Cir. 1955), denying enforcement to 109 N.L.R.B. 24 (1954), cert. granted, 350 U.S. 818 (1955).

11. 222 F.2d 316 (5th Cir. 1955), denying enforcement to 109 N.L.R.B. 485 (1954), cert. granted, 350 U.S. 818 (1955).

12. 225 F.2d 16 (9th Cir. 1955), denying enforcenent to 108 N.L.R.B. 1110 (1954), petition for cert. filed, 24 U.S.L. WEEK 3123 (U.S. Nov. 1, 1955) (No. 492).

13. Seamprufe, Inc., 109 N.L.R.B. 24, $29-31$ (1954) ; Babcock and Wilcox Co., 109 N.L.R.B. 485, 492 (1954) ; Monsanto Chemical Co., 108 N.L.R.B. 1110, 1118 (1954).

14. Seamprufe, Inc., supra note 13, at 29-31; Babcock and Wilcox Co., supra note 13, at 490, 492; Monsanto Chemical Co., supra note 13, at 1117-18.

15. Seamprufe, Inc., 109 N.L.R.B. 24, 29 (1954) ; Babcock and Wilcox Co., 109 N.L.K.B. 485, 491-92 (1954); Monsanto Chemical Co., 108 N.L.R.B. 1110, 1118-19 (1954). 
accomplished off company property and had ordered the company to admit union representatives. ${ }^{16}$

On appeal none of the courts found that solicitation off company property was sufficiently impeded to justify the Board's order. ${ }^{17}$ They reasoned that union organizers had adequate opportunity to solicit employees in town after working hours. ${ }^{18}$ Although all recognized that organizers may be granted access to an isolated site where employees both work and live, ${ }^{19}$ the decisions do not indicate what other circumstances would make opportunity for solicitation inadequate. Two of the courts merely declared that inadequate opportunity exists when there is an "impediment to union solicitation off company property amounting to a deprivation of the right of self-organization" and that absent such a showing the solicitors are "strangers to the right of self-organization."20

The courts' use of a "no-impediment" standard for measuring the adequacy of opportunity for solicitation off company property derives from an unwarranted interpretation of precedent. Early decisions had established that non-employees could solicit on company property where there had been discriminatory denial of the use of that property ${ }^{21}$ or where physical limitations of employment iso-

16. Seamprufe, Inc., supra note 15 , at 25,31 ; Babcock and Wilcox Co., supra note 15, at 486, 493-94; Monsanto Chemical Co., sippra note 15, at 1110, 1122.

17. NLRB v. Seamprufe, Inc., 222 F.2d 858, 861 (10th Cir. 1955); NLRB v. Babcock and Wilcox Co., 222 F.2d 316, 319 (5th Cir. 1955); NLRB v. Monsanto Chemical Co., 225 F.2d 16, 20-21 (9th Cir. 1955).

18. See note 17 supra. The Fifth Circuit, quoting Justice Reed's dissent in NLRB v. Stowe Spinning Co., 336 U.S. 226, 236 (1949), intimates that once the union has won over one employee, it must look to him to carry on solicitation at the plant. NLRB v. Babcock and Wilcox Co., supra note 17 , at 319 .

19. NLRB v. Seamprufe, Inc., 222 F.2d 858, 860-61 (10th Cir. 1955) ; NLRB v. Babcock and Wilcox Co., 222 F.2d 316, 318 (5th Cir. 1955); NLRB v. Monsanto Chemical Co., 225 F.2d 16, 19, 21 (9th Cir. 1955).

20. NLRB v. Seamprufe, Inc., supra note 19 , at 861 ; NLRB v. Monsanto Chemical Co., supra note 19, at 21 . These courts have also verbalized the standard as a "showing of non-accessibility amounting to a handicap to self-organization." NLRB v. Seamprufe, Inc., supra at 861 ; NLRB v. Monsanto Chemical Co., supra at 18-19.

21. NLRB v. Stowe Spinning Co., 336 U.S. 226 (1949) (non-employees granted access to meeting hall in company town used by other organizations for community purposes).Discrimination arises most frequently when no-solicitation rules are applied to favor one union only. E.g., International Ass'n of Machinists, AFL v. NLRB, 311 U.S. 72 (1940) ; NLRB v. Waterman Steamship Corp., 309 U.S. 206 (1940); Samuel Bingham's Son MIfg. Co., 80 N.L.R.B. 1612 (1948). A special problem arises when the employer delivers a noncoercive speech to employees during hours when solicitation is prohibited. Where the employer's no-solicitation rule applies to both working and nonworking hours, his speech is considered a discriminatory application of the no-solicitation rule, and he must afford a similar opportunity to the union. Bonwit Teller, Inc. v. NLRB, 197 F.2d 640 (2d Cir. 1952), cort. denied, 345 U.S. 905 (1953); NLRB v. American Tube Bending Co., 205 F.2d 45 (2d Cir. 1953). The Board has more recently held that when the employer does not enforce a no-solicitation rule during nonworking hours, it is not an unfair labor practice for him to make a speech during working hours and refuse a union request for the same opportunity. Livingston Shirt Corp., 107 N.L.R.B. 400 (1953). The Sixth Circuit has rejected the Bonzerit Teller doctrine and has ruled that it is not an unfair labor practice for an employer with a broad no-solicitation rule (department 
lated employees from outside contacts. ${ }^{22}$ On the basis of these decisions the Seventh Circuit, in Marshall Field \& Co. v. NLRB, ${ }^{23}$ had verbalized a general rule that discrimination and unique handicap were the exclusive criteria for non-employee access to company property under section $7 .{ }^{24}$ But the Seventh Circuit's application of its newly-discovered rule left its meaning in some doubt. For instead of examining the difficulties of soliciting off company property to see if an "impediment" to self-organization existed, the court analyzed the opportunity for solicitation on company property and found it already adequate..$^{25}$ In the instant cases, however, there was a complete absence of opportunity for solicitation at or even near the plant. ${ }^{26}$ Overlooking this factual distinction, these circuit courts relied on Marshall Field to deny access to non-employees 27 where the opportunity for solicitation was limited almost exclusively to home canvassing. In contrast to Marshall Field, these courts inspect the opportunity oif company property and determine that it is not so restricted as to constitute an impediment to self-organization. This determination is at best questionable, as contrary findings by the Fourth and Sixth Circuits on similar facts indicate. ${ }^{28}$ But whether or not the "no-impediment" standard was correctly applied, the fact remains that the instant cases fail to indicate why it should be used at all. Following the language of Marshall Field, these courts have simply assumed that the lumber camp case established an ultimate standard and that as long as non-employees have any opportunity for solicitation, however limited, employees' rights of self-organization are satisfied. ${ }^{29}$

Whatever privilege is to be accorded non-employee organizers to solicit on company property arises from employees' rights of self-organization guaranteed by section 7 . Since neither the terms of the statute nor its legislative history indicate the role of outside organizers under section 7,30 the scope of

store) to address the employees on working time. NLRB v. F. W. Woolworth Co., 214 F.2d 78 (6th Cir. 1954). See Note, 61 Yale L.J. 1066 (1952).

22. See cases cited note 8 sipra.

23. 200 F.2d 375 (7th Cir. 1952).

24. Id. at 379 .

25. The employer allowed non-employee organizers to solicit in the public cafeterias and at the store entrances. Id. at 382. Approximately 2,000 of the company's employees had been organized by other unions in this manner. Id. at 379 n.8. The court also granted non-employees access to a private company road bisecting the department store, which it likened to a public street. Id. at 380 .

26. See text at notes 14-16 sipra.

27. NLRB v. Seamprufe, Inc., 222 F.2d 858, 860 (10th Cir. 1955) ; NLRB v. Babcock and Wilcox Co., 222 F.2d 316, 318 (5th Cir. 1955) ; NLRB v. Monsanto Chemical Co., 225 F.2d 16, 20 (9th Cir. 1955).

28. NLRB v. Caldwell Furniture Co., 199 F.2d 267 (4th Cir.), enforcing 97 N.L.R.B. 1501, 1505-06 (1952), cert. denied, 345 U.S. 907 (1953) ; NLRB v. Ranco, Inc., 222 F.2d 543 (6th Cir, 1955), enforcing 109 N.L.R.B. 998, 1003-04 (1954), cert. granted, 350 U.S. 818 (1955). The decisions do not make clear whether the courts are applying the "nointerference" test of Republic or the "no-impediment" standard. Accord, NLRB v. Monarch Tool Co., 210 F.2d 183 (6th Cir. 1954). See note 7 supra.

29. See text at note 20 supra.

30. Efforts to amend the original act to curb the activities of labor unions were rusisted on the ground that labor unions had a legitimate interest in employee organization. $H \mathrm{~K}$. 
the statute must be determined against the factual background of modern industrial relations. In a complex industrial society employees cannot effectively exercise the right of self-organization without access to outside counsel, information and other aid. ${ }^{31}$ Employees lack both the experience and the organizational machinery requisite to successful organizing. ${ }^{32}$ Moreover, individual employees are naturally reluctant to take the initiative in action which may place them in disfavor with their employer. ${ }^{33}$ Thus, practical considerations dictate that the right of self-organization include the right to have outside organizers carry out solicitation activities.

Employees' right to outside aid is valueless, however, unless it includes the right to utilize that assistance at the place of work. The Supreme Court has recognized the plant as the place "uniquely appropriate" for organizational activities by employees. ${ }^{31}$ It is the most effective location for communication of information and opinion concerning labor organizations. ${ }^{35}$ Union meetings to organize employees after work ${ }^{36}$ or comprehensive individual solicitation off the premises are unsatisfactory substitutes. ${ }^{37}$ Section 7 should therefore be

Rep. No. 1147, 74th Cong., 1st Sess. 16 (1935) ; 79 CoNG. Rec. 7653-58, 7660-61, 7668-70 (1935).

31. See Thomas v. Collins, 323 U.S. 516, 534 (1945) ; NLRB v. F. W. Woolworth Co., 214 F.2d 78 (6th Cir. 1954) (dissenting opinion); Harlan Fuel Co., 8 N.L.R.B. 25, 32 (1938).

32. Employees must draw on outsiders with specialized skills. See DaugherTy, LABor Problems in American Industry 421-22 (5th ed. 1941); Hearings Before the Committee on Education and Labor of the Senate to Create a National Labor Board, 73d Cong., $2 \mathrm{~d}$ Sess., pt. 1, at 208 (1934) ; cf. NLRB v. Fansteel Metallurgical Corp., 306 U.S. 240, 248, 251 (1939) (unfair labor practice for an employer to refuse to meet with an employee committe because it was accompanied by an outside organizer).

33. Hearings Bcfore the Committec on Education and Labor of the Senate to Create a National Lahor Board, 73d Cong., 2d Sess., pt. 1, at 208 (1934). Senator Paul H. Douglas, then a professor of economics, testified that the employee's job and future are so dependent on the good will of the employer that he cannot act with the independence of an outsider. Ilid. Field studies indicate a deep-rooted feeling among workers that their future welfare depicnds upon "not crossing the boss." Note, 14 U. CHI. L. REv. 104, 108 (1946). See also Gardaner \& Moore, Human Relations in Industry 33-41 (rev. ed. 1950).

34. Republic Aviation Corp. v. NLRB, 324 U.S. 793, 801 n.6 (1945).

35. Eonwit Teller, Inc. v. NLRB, 197 F.2d 640, 645 (2d Cir. 1952), cert. denied, 345 U.S. 905 (1953); see Tomlinson of High Point, Inc., 58 N.L.R.B. 982 (1944) ; LincoLN, The Ciry or the Dinner-Pail 131 (1909); Thomas, Automobite Unronisa 11 (1941).

36. Organization through public meetings, particularly in smaller communities like those in which the instant cases arose, suffers from employee fear of incurring employer disfavor and risking discharge. See dissenting opinion of Board Member Murdock in Livingston Shirt Corp., 107 N.L.R.B. 400, 410 (1953). One union advises organizers to avoid methods requiring workers to identify themselves openly with the union. INTERNitional Ladies' Garment Workers' Union, Handbook of Trade Unton Miethods 11 (1937). Nor is it likely that workers will sacrifice their after-work hours to attend union meetings. Kopald, Democracy and Leadership, in BAKKe \& KerR, UnIoNs, MANagement, and the Public 180 (1948). Transportation problems also handicap the effectiveness of public meetings. See Livingston Shirt Corp., supra.

37. Home solicitation is burdened by the unavailability of home addresses, turnover in work force and factors of transportation, time and cost. See Livingston Shirt Corp., 
interpreted as requiring the employer to admit outsiders where their purpose is to promote organization.

Such an interpretation would not diminish the employer's ability to protect plant production and discipline from interference. Opportunity of non-employees to organize on company property would never exceed employees' privileges, which must always stop short of interference with plant efficiency. ${ }^{38}$ The Board has always allowed the employer to impose reasonable regulations on the union's access to and use of his property, requiring only that the rules bear some relation to the maintenance of efficiency and discipline. ${ }^{39}$ Rules denying non-employees access to functional parts of the plant fall into this category. ${ }^{40}$ Under certain circumstances the employer is warranted in prohibiting solicitation altogether upon his premises. For example, a context of disorder or labor violence would constitute circumstances justifying the imposition of rules that would otherwise be invalid. ${ }^{41}$

supra note 36 , at 422 (dissenting opinion). For the problems of organizers in effecting home solicitation, see Brooks, When LABor Organizes 2 (1937); Barbash, Lafor UNIONS IN ACTION 26 (1948). Home solicitation is most effective at the start of a campaign to convince a few key workers rather than as an instrument of mass communication. See Note, 61 YALE L.J. 1066, 1075 n.35 (1952).

38. See note 3 supra. Restrictions on solicitation during working hours may be made applicable equally to employees and non-employees. E.g., NLRB v. Montgomery Ward \& Co., 157 F.2d 486, 493-94 (8th Cir. 1946) ; McKinney Lumber Co., 82 N.L.R.B. 38, 43 (1949).

39. NLRB orders granting access to non-employee organizers specifically provide for reasonable regulation of that access. See, e.g., Seamprufe, Inc., 109 N.L.R.B. 24, 25 (1954) ; NLRB v. Lake Superior Lumber Corp., 167 F.2d 147, 150 (6th Cir. 1948). The employer may require organizers to register at the gate. Motor Freight, Inc., 57 N.L.R.B. 1340 (1944).

Disruption of aperating efficiency will enable the employer to curb otherwise permissible activities. Monarch Co., 56 N.L.R.B. 1749, 1752 (1949) ; National Screw \& Mfg. Co., 51 N.L.R.B. 583, 586, 589 (1943). But the employer must bear the burden of showing a correlation between declining production and solicitation. Union Mfg. Co., 63 N.L.R.B. $254 \&$ n.2 (1945).

Restrictions become unreasonable when extrinsic cvidence shows that the primary purpose is to curb organization. Kohen-Ligon-Folz, Inc., 36 N.L.R.B. 1294, 1299-1303, cinforicd, 128 F.2d 502, 503 (5th Cir. 1942) ; Odenbach Shipbuilding Corp., 64 N.L.R.B. 1026 (1945).

40. E.g., Colonial Shirt Corp., 96 N.L.R.B. 711 (1951) ; Westinghouse Elec. Corp., 91 N.L.R.B. 955 (1950) ; Tabin-Picker \& Co., 50 N.L.R.B. 928 (1943). If the employer affords adequate opportunity for solicitation he may restrict the right to distribute literature to particular areas. E.g., Monolith Portland Cement Co., 94 N.L.R.B. 1358 (1951) ; Brown Shipbuilding Co., 66 N.L.R.B. 1047 (1946) ; Goodyear Aircraft Corp., 57 N.I.R.B. 502 (1944).

41. E.g., Boeing Airplane Co. v. NLRB, 217 F.2d 369 (9th Cir. 1954) (tense atmosphere following termination of strike) ; Johnson-Stephens \& Shinkle Shoe Co., 54 N.I.R.E. 189, 192 (1943) (violence); Nash-Kelvinator Corp., 18 N.L.R.B. 738, 741-44 (1939) (forcible eviction of inspectors); see NLRB v. Aintree Corp., 135 F.2d 395, 397 (7th Cir. 1943) (rival union literature taunted so-called company union) ; $c f$. Maryland Dry* dock Co. v. NLRB, 183 F.2d 538 (4th Cir. 1950) (employer may properly forbid distribution of union literature of a defamatory nature).

Mere probability of violence may constitute special circumstances justifying restriction, but the burden rests on the employer to show that the probability exists. Kimble Glass 
Section 7 does not grant outside organizers a right to solicit on company property independent of employees' right of self-organization. The courts in the instant cases properly declare that some relationship should exist between the organizers and the employees. ${ }^{42}$ But it would be grossly unfair to demand that the union be the employees' bargaining agent or that some employee belong to the union as the court in Seamprufe suggests. ${ }^{43}$ Babcock would apparently require some evidence that organizers are working in concert with or have been solicited by the employees. ${ }^{44}$ Even this seems unjustified since requiring any une employee or group of employees to express their interest in having outside organizers come in would unfairly distinguish them from their fellow workers and expose them to reprisals. It would seem proper to infer the requisite relationship from all the circumstances, with the aid, if necessary, of a presumption of interest by employees absent an affirmative showing to the contrary. Under this approach it is reasonable to conclude that a sufficient employeeorganizer relationship existed in the instant cases. ${ }^{45}$

For future cases, however, requirement of proof of an employee-organizer relationship may precipitate unfair results. Any efforts by an employer to demonstrate employee lack of interest in outside organization will inevitably tend to inhibit free expression by some employees. This potential barrier to employee organization could be avoided by not requiring that the relationship exist between organizers and employees of the particular plant. It can be argued that section 7 guarantees to employees the right to induce workers at other plants to join their union in order to strengthen their bargaining position. Section 2 of the NLRA specifies that the term "employee" is not limited to the employees of a particular employer. ${ }^{46}$ Regardless of whether the organizers' aid is requested by employees of the particular plant or by employees elsewhere who are members of the organizing union, once the organizer-employee relationship is established, the courts' imposition of a "no-impediment" standard is an unjustified barrier to effective self-organization.

Co., LAB. ReL. Rep. (36 L.R.R.M. 1340) (NLRB Aug. 11, 1955) ; Caterpillar Tractor Co., LAB. REL. Rep. (36 L.R.R.M. 1336) (NLRB Aug. 11, 1955).

42. NLRB v. Seamprufe, Inc., 222 F.2d 858, 861 (10th Cir. 1955) ; NLRB v. Babcock and Wilcox Co., 222 F.2d 316, 319 (5th Cir. 1955) ; NLRB v. Monsanto Chemical Co., 225 F.2d 16, 18, 21 (9th Cir. 1955).

43. NLKB v. Seamprufe, Inc., supra note 42 , at 861 .

44. NLRB v. Babcock and Wilcox Co., 222 F.2d 316, 317-18 (5th Cir. 1955).

45. While the cases lack details concerning an employee-organizer relationship, there in no showing which negates the presumption of interest.

46. 49 Stat. 450 (1935), as amended, 29 U.S.C. $\$ 152$ (1952). 